\title{
e-CALF (Electronic Version of Contextual Attractive Logical Fun) Game as Self-Directed Learning Media for Students in the Digital Era
}

\author{
N.W.S. Mahayanti ${ }^{1}$, G.A.P. Suprianti ${ }^{2}$, I.A.M.I. Utami ${ }^{3}$, I.P.I. Kusuma ${ }^{4}$ \\ ${ }_{1,2,3}$ English Language Education, Faculty of Language and Art, Ganesha University of Education, Indonesia \\ ${ }^{4}$ Western Michigan University, United States \\ e-mail: mahayantisurya@yahoo.co.id, gap.suprianti@undiksha.ac.id, istriutami@undiksha.ac.id, \\ indra.kusuma@undiksha.ac.id
}

\begin{abstract}
The study aimed at developing a prototype digital game e-CALF (electronic version of Contextual Attractive Logical and Fun) as self-directed learning media for elementary school students. The research was conducted in SD Lab Singaraja in which the subjects of the study were one class representative in each grade of the students. The design of this research was adapted from ADDIE Model. The data was gained by using interview guide, observation sheet, questionnaire and expert judgement rubric. Since it was found that almost $90 \%$ of students in SD Lab Undiksha have their own smartphone, it is a need to design digital media which can facilitate them doing self-directed learning at home. As the result, e-CALF is designed, developed, and revised and at the end of this study, the e-CALF can be categorized as an excellent media. The score of the material was given by the first, second, and third judges are 110,110.5, and 111. Those scores are in a range of $X \geq 103.5$ which is categorized as an excellent content. From media expert, the accumulation score gained is 148 . The score is in a range of $X \geq 139.5$ which is also categorized as an excellent media.
\end{abstract}

Keywords: e-CALF, digital game, self-directed learning, digital native

\section{Introduction}

In teaching foreign languages, especially English, the application of digital games has become commonplace. In addition to helping students improve vocabulary mastery (Aghlara\&Tamjid, 2011; AlShaiji, 2016; Ashraf, Ghanei, \& Salami, 2014; Aslanabadi\&Rasouli, 2013; Jafarian\&Shoari, 2017; Meihami, Meihami, \&Varmaghani, 2013; ranali, 2008 ; Segers\&Verhoeven, 2003; Turgut\&Irgin, 2009; Yudintseva, 2015), playing digital games can also hone students' problem solving abilities (Chalak\&Ahmadi, 2017; Chuang \& Chen, 2007; Donmus, 2010; Gee, 2007; Gee , 2005). With digital games, students get the opportunity to interact with the English language used in the game without being burdened. Digital games have rules, clear goals, are interactive and adaptive, accompanied by feedback that makes the game very enjoyable (Prensky, 2001) and can attract the attention of students as players for hours and days (Prensky, 2001; Gee, 2003). Because playing digital games is very fun for students without feelings of worry and stress (Jafarian\&Shoari, 2017), they will not mind playing it for hours until they reach the target or goal of the game (Eskelinen, 2012).

Korkmaz (2013) states that teaching English with games is one of the best ways to provide entertainment in line with language learning itself. With the use of digital games, teachers and parents are sure that their children have been prepared to explore, both in reading and writing activities. Rankin, McNeal, Shute, \& Gooch (2008) found that in addition to accommodating the specific objectives of second language learning such as vocabulary and speaking skills, digital games also accommodate students' reading comprehension very well. Also found, in digital games, students practice reading skills by understanding the meaning of texts without having to know the meaning of each word (Eskelinen, 2012). It was revealed by Wolley (2011) that reading comprehension is the process of interpreting a text where the function of reading itself is to gain a thorough understanding of the reading, rather than interpreting it word for word separately. Thus, digital games can be used as a solution to improve students' abilities, especially children, in reading comprehension. 
The success of the application of digital games in learning English in class certainly cannot be separated from the teacher's attitude towards its implementation (Anyaegbu, Ting, \& $\mathrm{Li}, 2012$ ). The results of Egenfeldt-Nielsen's (2011) study revealed that foreign language teachers believe that there is great potential for students to learn from games when compared with other subject teachers. Based on the results of the initial interviews conducted, although teachers in elementary schools in Buleleng regency have never integrated digital games in classroom learning, they have doubts and reluctance to implement them due to the time factor. To compensate for the demands of the curriculum, exposure to the material in the class races with time, so that the pleasure aspects of students are slightly ignored. Furthermore, they realized that if students had the opportunity to learn while playing, far better results would be achieved. This is in line with what Meyer (2013) revealed in which it is stated that games are usually difficult to integrate with formal learning.

Furthermore, Meyer (2013) revealed that the solution that can be taken is to use digital games as self-assisted learning media. This supports exposure (Scanlon \& Buckingham, 2007) which says that homes will be increasingly seen as school extensions. As a consequence, students will be required to learn independently at homes, and with digital games, these additional tasks will be very enjoyable for students. Delivered by Waschk (2004) that the experience of using online learning in children's education shows that online material, if well designed and appropriate, can support learning in providing input, sustaining, and giving positive feedback. Digital games, if used properly, will provide contextual input in language learning and provide challenges and competitions involving students in self-assisted learning (Baltra, 1990; Crookall, 2007; Li \&Topolewsky, 2002; Garcia- Carbonell, Rising, Montero, \& Watts, 2001).

The next consideration that teachers think about in Buleleng Regency is about the suitability of digital games with the demands of curriculum and school. Although Stanley (2012) revealed that there are a lot of readings contained in digital games such as game instruction, game goals, conversations in games between characters, etc., but to get games that are truly in line with curriculum topics and demands and in accordance with students' initial abilities are very challenging.

Mahayanti (2017) has designed a game called CALF (Contextual, Attractive, Logical, and Fun) that is effectively used in teaching reading comprehension. The game is designed in the form of a game equipped with supporting material for each topic that matches the syllabus. CALF facilitates students to learn gradually, ranging from vocabulary mastery, filling in sentences, to answering understanding questions. With the help of the media, students learn in a fun way. However, it is unfortunate that the media in the form of wood requires substantial costs to be mass produced. In addition, if we go back to the term 'digital native', the use of manual media such as CALF will begin to be abandoned by students. It will be more effective if the CALF concept can be packaged by digitizing the game in the form of new e-CALF game media. Thus, when children are at home, they can still play eCALF digital games in their hands (handphone). In connection with the explanation and consideration as mentioned earlier, this study aims to develop a digital game of e-CALF as a medium for self-assisted elementary school students in reading comprehension.

\section{Methods}

This research is a research and development (Reseach and Development) aimed to develop a digital game prototype e-CALF as an independent learning media for elementary students by using the development model of ADDIE (Analysis, Design, Development, Implementation, and Evaluation) which is limited to the development stage. In its implementation, several instruments such as interview guides, questionnaires, and rubrics for expert assessment were used. The overall instrument used in this study measured its validity. The validity test involved 2 experts and the validity tested was content and construct validity. These components are assessed with a very appropriate scale, quite appropriate, inappropriate, and very inappropriate. Experts are also asked to comment on the products that are developed in a concise manner, including general assessments, strengths that need 
to be maintained, and weaknesses that need to be corrected. After obtaining the data, the analysis was carried out qualitatively and quantitatively.

\section{Results and Discussion} namely:

In developing e-CALF game media, there are several steps taken by researchers,

\section{a. Analysis}

At this stage, an analysis is carried out to find out the potential and problems faced by elementary students in suburban areas such as Singaraja. At this stage, interviews and questionnaires were conducted. From the results of the student questionnaire analysis, the researchers found that most students have their own mobile phones which they usually use at home. Of the 38 students in grade $4 \mathrm{~A}$ for example, 20 students had their own mobile phone, while at 4B, out of 38 students, 24 students had their own mobile phone. In this case, we know that students have used cell phones even though they are still students who are young learners. Also found that most of them use cell phones to play games, update social media, search for information on the internet, and watch videos. Regarding permission to use cell phones, most students have obtained permission from their parents to use their own cell phones with a variety of different restrictions between one student and another. Regarding the duration of their use of cell phones, most students use it for about one to three hours per day. Researchers also ask students about the games on their cell phones whether they are related to the lessons in school or not. The students answered that some of the games they play are related to school lessons, and some other games do not. Most of the languages used in games on their mobile phones are English even though there are some that are Indonesian. Unfortunately, most of them said that they do not understand the English language instruction in the game because of the limited understanding of English vocabulary.

In this case, researchers found that most students have used cell phones as young students, where it has a high risk when they focus too much on the game, they will play until they forget to study. Second, researchers found that students mostly play games that are not related to the lessons taught at school. In this case, students may not get a positive impact from playing games on their cell phones in terms of learning achievement. Third, researchers found that students do not really understand the language used in the games they play on their cell phones, especially English. The observations were then used as the basis for developing a game called e-CALF, so that students could use their cell phones to play games, where they could also learn English, especially in improving their reading comprehension and in accordance with the applicable curriculum.

The same thing was found from the results of interviews with English teachers at school. Based on the results of the interview, it is revealed that the teacher definitely supports the existence of digital media which is certainly will be interesting and interactive. However, it was also stated that the problem was that students were not allowed to take their cellphones to school which caused high risk. As a solution, the teacher agrees that students can play cellphone games in the form of cellphone games at home. Regarding the content in the media needed by elementary students, the teacher answers that content must be simple, can motivate students to continue learning, and consists of images to attract students' attention.

In addition to interviews with teachers and students, syllabus analysis also needed to be done to make the contents of the product in accordance to the syllabus such as topics and competencies that must be achieved by students in learning English. Syllabus analysis is used as a guide in designing product content. This also gives material constraints so that the contents are not too broad and not too narrow. Thus, the contents of the product can be in accordance with the needs of students.

In analyzing the syllabus, English teachers are involved. The teacher is asked to fill out a syllabus list to determine the topics that should be developed in the game product in this study. The teacher chooses four topics from the second semester at each grade level to 
develop. From the results, it was found that there were four topics that had to be developed as mobile games at each grade level so that overall, there were 24 topics developed as Ecalf content in this study.

\section{b. Game Design}

As the next procedure of this study, the preparation of media and supporting materials was based on syllabus analysis, drafting of media based on the draft, assessment by several experts, and revisions were made to design a media prototype called e-CALF as a mobile game to improve reading comprehension of elementary students.

In addition to the media, there are also supporting materials that have been designed. The material is divided into four topics for each grade level, based on the topics required by the syllabus, where each topic consists of six levels. In each topic, there are 2 levels of vocabulary related to the topic, 2 levels of filling in the blank text, and 2 levels of understanding texts with questions.

After completing the blueprint, several related sources and references, including text and images, were collected. By utilizing the results of the analysis carried out when planning and designing the blueprint, the media was developed systematically. The media was created with assistance in making the program by a team of programmers from the Informatics student group, which was based on the blueprint and pictures designed by researchers. Examples of concrete illustrations can be seen in the following figure.


Figure 1. Class 1 Media Design Topics 1 (Family)

Based on figure 1, it can be seen that the supporting material in making e-CALF media is designed in interesting and attractive ways, using contextual images with attractive colors so that students become motivated in solving problems related to their reading comprehension logically. The material has also been systematically compiled based on the 
syllabus used by the schools so that in the end it can be an alternative learning media for students at home to achieve their learning goals.

After compiling and designing media material, the next step is to conduct an expert assessment. Based on the rubric filled by the two experts, there are some things that still need to be revised and improved, such as consistency in the form and size of the writing, the selection of the right words, grammar, etc. In addition, the first expert stated that the topic was in accordance with the curriculum and characteristics of students. Excellence in content before revision is about the suitability of images that are relevant to reality. In addition, the layout is good, the design is simple and attractive, so students will be able to enjoy the game. In addition to this, the media is good because it facilitates students with vocabulary, word usage, and reading comprehension in sequence. On the other hand, the weakness of this product is that there are still some grammars errors. There is a need to improve some writing fonts so it can be consistent and improve the grammars that are still wrong.

Based on the results of expert test calculations 1,2 and 3, it was found that the first total expert score was 88 which was categorized as a good media. Furthermore, the second expert obtained a total score of 107 which was categorized as an excellent media. The conclusion, from the three classifications of results in rubric material, it can be categorized as "good media".

After conducting expert tests based on material design, the researcher revised the design. In this phase, the design of e-CALF from researchers has several inputs and assessments from experts. There are several revisions in the form of word selection, grammar, images, and differences. The examples of revisions that have been made can be seen in the following figure.



Figure 2. Vocabulary Improvement

After revising the material based on the input from material experts, the next step is to conduct an expert assessment after revising the material. Based on the calculation of expert tests 1 and 2, it was found that the first total expert score was 110 which was categorized as a good media. Furthermore, the second expert obtained a total score of 113 which was categorized as an excellent media. In conclusion, based on the assessment of experts, the resulting media can be categorized as a "very good media". 


\section{c. Develop (Development)}

As the next procedure of this research, the development of media and supporting materials is based on syllabus analysis, evaluating material and media experts, consulting several experts, and revising the product to design a media prototype called e-CALF as a mobile game to improve students' reading comprehension in elementary school.

Development of Android-based games in this study was developed through several stages of programming. After developing a product using the Construct2 application based on previously designed material, the next step is to conduct expert assessments by media experts. Based on the results of the assessment by media experts, it was found that the developed media received a score of 117 which meant that the media was categorized as a good media. Therefore, it can be said that the content in e-CALF digital games is good, but there must be some technical related improvements, such as removing the narrative button, entering a tutorial before playing the game, changing the color of pins in the color topic (vocabulary 1 and level 2 vocabulary), changing the texture of the pin to 3D, changing the position of the 'back' button, changing the position of the answer words in the game to the left and entering the pop-up menu when exiting the game. The following are examples of improvements made.

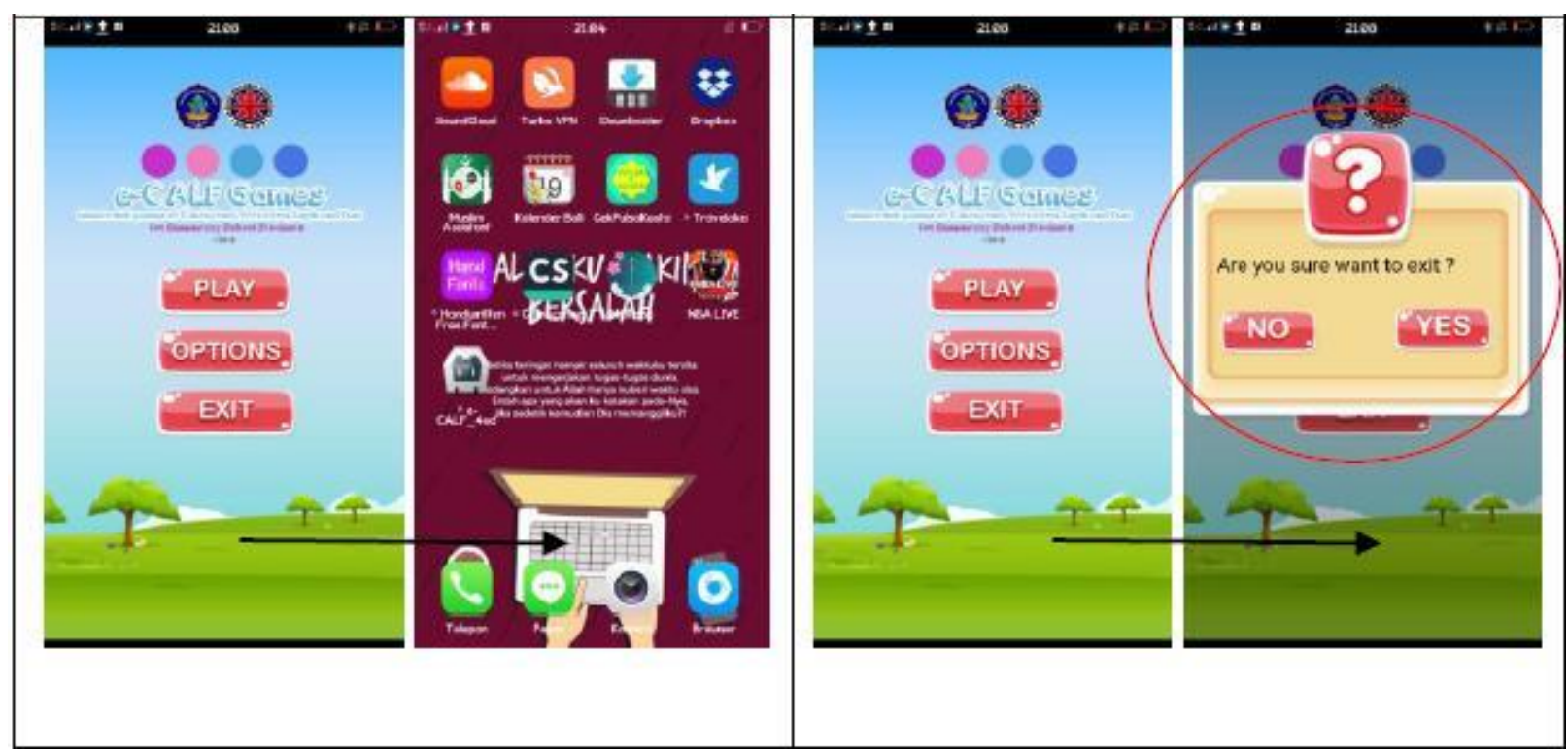

Figure 3. Media Revision 1

After doing the revision process, the next step is to do an expert assessment by media experts after the media revision. Based on the results of the rubric for calculating media ratings in the e-CALF game, it was found that the total score was 148 . The score was categorized as excellent media. Therefore, it can be said that the content of e-CALF digital games is very good.

After assessing experts from material experts and media experts, the researcher has finished making the final product prototype of the e-CALF game. The final prototype product details are explained below. 
Table 1. Final Product Prototype from e-CALF game

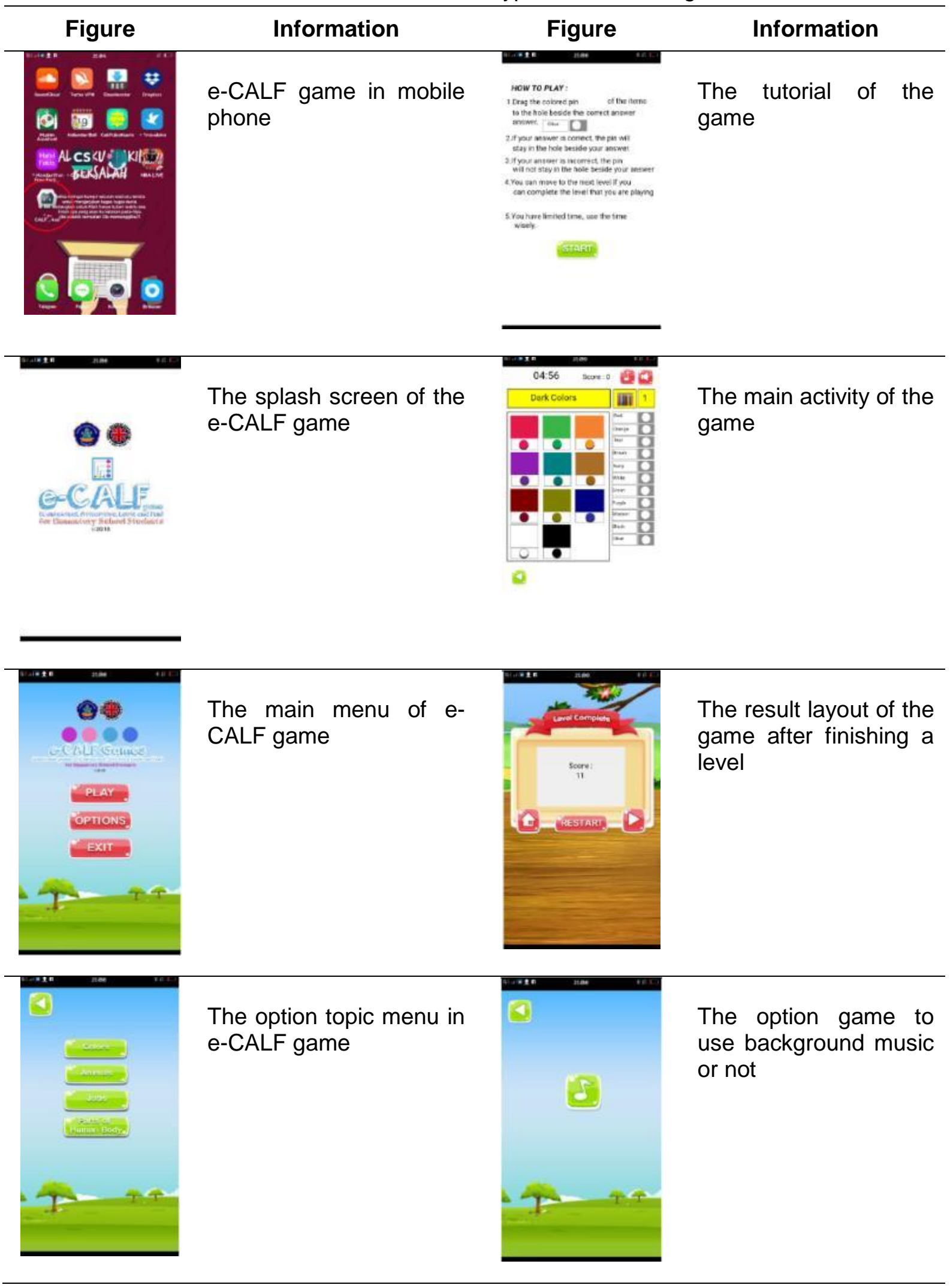




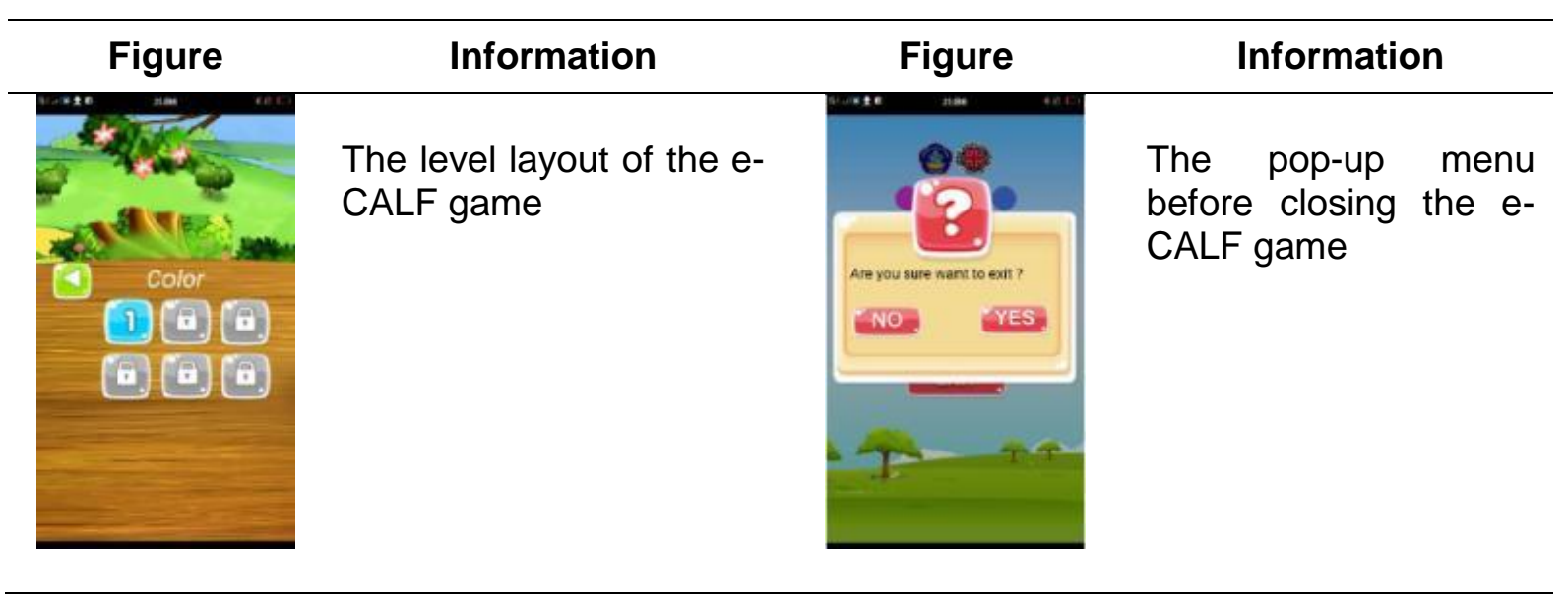

As stated in the findings, the purpose of conducting this research was to develop a digital game of e-CALF as a Self-Directed Learning Media for fourth-grade students at UNDIKSHA Lab SD Singaraja. The media is in the form of cellular phone applications developed based on syllabus analysis, consultation and revision of materials, and media development.

Based on the results of the needs analysis, it can be concluded that most of the students in elementary school have their own mobile phone and play digital games in it. It is in line with Lenhart, et al (2008) who mention that $97 \%$ children between 12 to 17 years old play games in computer, online website, mobile devices, or video game tools. Project Tomorrow: SpeakUp (2008) also found that elementary school students (grade 3-5) play online games (54\%). From those results, it can be concluded that children in that age really like playing games with electronical devices. We cannot deny that phenomena because they were born with technology in their hands and even Uhls (2015) mentions Z generations are experts in using tablet before they can wear their shoes by themselves. Considering the results, it is crucial to consider appropriate media to facilitate them learning better.

Uhls (2015) also mentions that playing is a part of human DNA, especially for children. By playing, children can learn many things subconsciously because they enjoy the process. From the results of this study, it is also found that they have learnt English while playing the game in their mobile phone. Playing games gives many beneficial impacts for students. It helps students improving vocabulary mastery (Aghlara\&Tamjid, 2011; AIShaiji, 2016; Ashraf, Ghanei, \& Salami, 2014; Aslanabadi\&Rasouli, 2013; Jafarian\&Shoari, 2017; Meihami, Meihami, \&Varmaghani, 2013; Ranali, 2008; Segers\&Verhoeven, 2003; Turgut\&Irgin, 2009; Yudintseva, 2015). Playing digital games can also hone students' problem solving abilities (Chalak\&Ahmadi, 2017; Chuang \& Chen, 2007; Donmus, 2010; Gee, 2007; Gee, 2005). The students can be in toucht with the target language (English) in fun atmosphere without feelings of worries (Jafarian\&Shoari, 2017) and it make them will not mind playing it for hours to reach the goals of target language (Eskelinen, 2012; Prensky, 2001; Gee, 2003).

In line with the results of the observation, the results of the questionnaire show that students need supporting media that can make them learn not only in the classroom but also outside the classroom. That's because, in class, students only learn through activities directed by the teacher. This statement is supported by Porvaldsdŏttir (2008) which states that there are five important characteristics possessed by young students, they are selfcenteredness, short attention span, learning through the senses, having a natural curiosity, and learning through play. In this case, the short attention span of students in class activities is not a maximum effort because students' nature is easily bored. In addition, Porvaldsdŏttir (2008) also added that students learn through play. Thus, e-CALF media is a suitable medium that can accommodate students' need to improve their reading comprehension outside the classroom. In addition, it is also related to students' motivation in learning, 
because they complete the game with great enthusiasm. This means motivation is a force that encourages employees to work towards their goals and is often manifested in their willingness, desire, or commitment to perform tasks that will lead to the achievement of goals (Churchill, et al. 1985 in Boyer et al. 2016). In addition, Garrison in Abdullah (2001) states that they want to know and want to try new things, see problems as challenges, desire to change, and enjoy learning. So, e-CALF games can support students' independent learning to improve their reading comprehension.

In developing the game, researchers also consulted with material experts and media experts. There are several revision processes during game development. In this case, researchers want to make a good game so students enjoy playing games and can also make students satisfied with the game. This relates to the theory of Al-Hamash et.al (1980) proposing several points that must be considered in using games for educational purposes, such as games must be simple enough to be understood and played by all students and good games is one that contains elements of surprise or competition. In this case, the eCALF game has a simple rule that is to drag and drop the pin to the correct answer. In addition, this game also has a tutorial before playing the game, which relates based on the theory of Al-Hamash above. In the e-CALF game, there is also a countdown that can make students more enthusiastic in playing games.

The expert assessment results were analyzed using the standard deviation formula proposed by Rifai (2015) in the expert assessment before the revision process, and using the formula proposed by Nurkancana\&Sunartana in Mahayanti (2017). In the material expert before the revision, the first expert judge scored 88, the second expert judge gave a score of 107, and the third expert judge scored 89. For the media expert before the revision, the expert judge gave a score of 117 . Overall, this was categorized as a good media, but it must be corrected in several aspects such as the grammar revision in the material, and also the layout and sound in the media revision.

After the revision process, the first expert judge scored 110, the score of the second expert judge was 113 and the third expert judge scored 111. From the media expert, the score given for the e-CALF game was 148. This means the rating of the e-CALF game as an extraordinary medium. That's because the development and revision of the game have followed expert advice and also relates to theories in theoretical and empirical reviews. This can be attributed to the theory by Uberman (1998) which asserts that a game can be said to be a good game if the rules are simple, clear and uncomplicated. In this case, this is due to an expert judgment rubric that contains the simplicity of the game and the efficiency of the rules. In addition, the results of the empirical review from Mahayanti (2017) also reflected CALF's conventional media before developing the e-CALF game. The results of the research from Mahayanti are an excellent prototype media called CALF that was designed. As an implication, group work can be done effectively in school settings. Furthermore, Budiarta's research on CALF in 2015 was also successful, where the use of CALF media in group work activities can help students in listening. From the results above, it can be concluded that the use of CALF Media in Working Group activities can improve students' listening ability.

However, research on the development of e-CALF digital games as Self-Directed Learning Media is imperfect. Besides its strength, this media also has weaknesses. The power of this media is simple and easy to use by users because its illustrations and activities can be an alternative medium for learning English by students, especially improving their reading comprehension outside the classroom. Meanwhile, the weakness of this hidden object media is in terms of implementation. In implementing hidden object media, the game's sound is opened less automatically, and must first click to use game music before playing the game. Thus, the music can be better if played automatically when the game is opened.

\section{Conclusions and Suggestions}

This research is a Research and Development which aims to develop e-CALF digital games as Independent Learning Media for fourth-grade students of elementary schools at UNDIKSHA Lab Elementary School Singaraja. Based on the results of the analysis in the previous chapter and the problem statement, the authors reached the conclusion that four 
topics were developed into e-CALF games at each grade level in this study. Each topic contains six levels such as vocabulary 1 and 2, filling in blanks 1 and 2 , and understanding 1 and 2. In addition, the product of this study was designed based on syllabus analysis, good games, and following the judgment of experts.

After conducting research and development, analyzing data and discussing the results, the authors provide some suggestions to those who might benefit from the results of this study. It is recommended for teachers to use the game as an alternative medium for improving students' reading comprehension outside the teaching and learning process in school. This is because students have a short attention span while in school during the learning process. So, this application can support students' need to learn while playing games and they can learn through independent learning outside the classroom.

Because the product of this research is a prototype game, it may need further improvement. It is recommended for other researchers to continue this research by conducting field testing of this product. In addition, the subjects involved were very limited which only occurred in the fourth-grade students at UNDIKSHA Singaraja Lab Elementary School, it was also suggested for other researchers to continue this study by applying greater participation to product field testing of this study in other schools.

\section{References}

--- (2015). Growing Wireless: Quick Facts. http://www.growingwireless.com/get-thefacts/quick-facts

Abdullah, M. H. (2001). —Self-Directed Learning. Educational Resource Information Center (U.S. Department of Education) II. Retrieved from http://www.education.com/reference/article/Ref_Self_Directed// (Accessed on January 1, 2018)

Aghlara, L. \& Tamjid, N.H. (2011). The Effect of Digital Games on Irian Children's Vocabulary Retention in Foreign Language Acquisition. Procedia-Social and Behavioral Sciences 29(2011) 552-560.

Al-Hamash, Khalil, I., \& Rahim, S. A. (1980). - Teaching English as a foreign languagell. Third Edition. Baghdad: Ministry of Education Press, No.1.

AIShaiji, O.A. (2016). Video Games Promote Saudi Kids English Vocabulary Retention. Second Asia Pasific Conference on Contemporary Research, pp. 106-115.

Anyaegbu, R., Ting, W. \& Li, YI. (2012). Serious Game Motivation in an EFL Classroom in Chinese Primary School. The Turkish Online Journal of Educational Technology Vol 11 Issue 1 pp. 154-164.

Ashraf, H., Ghanei, M.F., \& Salami, M. (2014). The Impact of Online Games on Learning English Vocabulary by Irian (Low-Intermediate) EFL Learners. ScienceDirect, 98: 286291.

Aslanabadi, H. \& Rasouli, G. (2013). The Effect of Games on Improvement of Irian EFL Vocabulary Knowledge in Kindergartens. International Review of Social Sciences and Humanities, 6(1): 186-195.

Baltra, A. (1990). Language Learning Through Computer Adventure Games. Simulation \& Gaming Vol 21 No 4 pp 445-452.

Boyer, S. L., Edmondson, D. R., Artis, A. B., Fleming, D. (2016). —Self-Directed Learning: A Tool for Lifelong Learningll. Journal of Marketing Education 2014, Volume 36, Number 1 (pp. 20-32).

Chalak, A. \& Ahmadi, B. (2017). Integration of Serious Games in Teaching English as a Foreign Language to Iranian Children. International Journal of Foreign Language Teaching \& Research, Vol 5 Issue 17, pp 77-87.

Chuang, T.Y. \& Chen, W.F. (2007). Digital Games for Cognitive Learning: A Pilot Study. Journal of Scientific and Thechnological Studies, 41(1), pp 17-27.

Crookall, D. (2007). Editorial. Second Language Acquisition and Simulation. Simulation and Gaming Vol 38 No. 1, pp.6-8.

Donmus, V. (2010). The Use of Social Networks in Educational Computer-Game Based Foreign Language Learning. Procedia-Social and Behavioral Sciences. 
Egenfeldt-Nielson, S. (2007). Third generation educational use of computer games, Journal of Educational Multimedia and Hypermedia, 16(3), 263-281.

Eskelinen, S. (2012). Applying Video Games in Language Learning and Teaching: The Learner Perspective: a Case Study. Bachelor Thesis: University of Jyvaskyla.

Garcia-Carbonell, A, Rising, B., Montero, B., and Watts, F. (2001). Simulation/Gaming and the Acquisition of Communicative Competence in Another Language. Simulation and Gaming Vol.32 No.4, pp.481-491.

Gee, J. (2003). What Video Games Have to Teach Us About Learning and Literacy. New York, NY: Palgrave Macmillan

Gee, J. (2005). Why Video Games Are Good for Your Soul: Pleasure and Learning. Melbourne: Common Ground.

Gee, J. (2007). What Video Games Have to Teach Us About Learning and Literacy. Revised and Update Edition. New York, NY: Palgrave Macmillan

Jafarian, R.B. \& Shoari, E. (2017). The Effect of Games on Irian Young EFL Learners' Vocabulary Learning. European Journal of Emglish Language and Literature Studies. Vol 5, No.5, pp 12-24.

Korkmaz, S.C. (2013). Language Games as A Part of Edutainment. Procedia-Social and Behavioral Sciences 93 (2013) 1249-1253.

Lenhart, A., Kahne, J., Middaugh, E., MacGill, A., Evans, C., dan Vitak, J. (2008). Teens, Video Games and Civics Pew Internet and American Life Project. Washington DC: Pew Research Center

Li, R.C. \& Topolewski, D. (2002). ZIP \& TERRY: A New Attempt at Designing Language Learning Simulation. Simulation and Gaming Vol 33 No 2, pp. 181-186.

Mahayanti, N. W. S. (2017). Developing CALF (Contextual, Attractive, Logical, And Fun) Media to Teach Reading for Young Learners. International Journal of Language and Literature. Vol.1, No.2, May. 2017. ISSN:2549-4287. Universitas Pendidikan Ganesha.

Meihami, H., Meihami, B., \& Varmaghani, Z. (2013). CALL in the Form of Simulation Games: Teaching English Vocabulary and Pronunciation through Sims. International Letters of Social and Humanistic Sciences. 8. Pp. 57-65.

Meyer, B. (2013). Game-Based Language Learning for Pre-School Children: A Design Perspective. The Electronic Journal of e-Learning Vol. 11 Issue 1 pp 39-48.

Musthafa, B. (2010). - Teaching English to young learners in Indonesia: essential requirementsll. Educationist Journal. Volume 4, Number 2 (pp. 120-125).

Porvaldsdóttir, H.G., (2008). Songs as teaching resources in the young learners' ESL Classroom. [online] Available from: http://skemman.is/stream/get/1946/1590/4824/1/Microsoft_Word_ThesisGydaFinalEd ition.pdf [Accessed 29 October 2017]

Prensky, M. (2001). Digital Natives, Digital Immigrants. On the Horizon 9 no 1: 1-6

Ranalli, J. (2008). Learning English with the Sims: Exploring Authentic Computer Simulation Games for L2 Learning. Computer Assisted Language Learning, 21(5), pp. 441-455.

Rankin, Y. A., McNeal, M., Shute, M. W., and Gooch, B. (2008). User-centered game design of serious games for second language acquisition. In Conference Proceedings of ACM SIGGRAPH '08 Sandbox, Los Angeles, CA. August 11 - 18, 2008.

Scanlon, M. and Buckingham, D. (2007) 'Home learning and the educational marketplace', Oxford review of education vol. 30, no. 2, pp. 287-303

Segers, E. \& Verhoeven, L. (2003). Effects of Vocabulary Training by Computer in Kindergarten. Journal of Computer Assisted Learning, 19. 557-556.

Stanley, G. (2012). Language Teaching and Learning: Online Digital Games and Gamification. Digital Play

Turgut, Y. \& Irgin, P. (2009). Young Learners' Language Learning Via Computer Games. Procedia-Social and Behavioral Sciences 1 (2009) 760-764.

Uhls, Y.T. (2015). Media Moms and Digital Dads: Menjadi Orang Tua Bijak di Era Digital. Tiga Serangkai Publishing Group: Solo

Waschk, K. (2004) 'Lernverhalten von Kindern im offenen Fremdsprachenunterrich mit Multimedia und Lernsoftware', Frühes Deutch vol. 2, pp. 21-23 
Wolley, G. (2011). Reading Comprehension: Assisting Children with Learning Difficulties. DOI 10.1007/978-94-007-1174-7_2. [online] Available from: https://theliteracywiki.wikispaces.com/file/view/Woolley+-+2011++Reading+Comprehension.pdf [Accessed 20 October 2017]

Yudintseva, A. (2015). Game-Enhanced Second Language Vocabulary Acquisition Strategies: A Systematic Review. Journal of Social Sciences, 3, 101-109 http://dx.dio.org/10.4236/jss.2015.310015 